\title{
The MCS macroseismic survey of the Emilia 2012 earthquakes
}

\author{
Paolo Galli ${ }^{1,}$, Sergio Castenetto ${ }^{1}$, Edoardo Peronace ${ }^{2}$ \\ ${ }^{1}$ Dipartimento della Protezione Civile, Roma, Italy \\ ${ }^{2}$ Istituto di Geologia Ambientale e Geoingegneria, Consiglio Nazionale delle Ricerche (CNR-IGAG), Monterotondo Scalo, Italy
}

\author{
Article history \\ Received July 25, 2012; accepted September 4, 2012. \\ Subject classification: \\ Macroseismic survey, MCS scale, Emilia 2012 earthquake, Historical seismology.
}

\section{Introduction}

Most of the inhabitants of northern Italy were woken up during the night of May 20, 2012, by the $\mathrm{M}_{\mathrm{W}} 6.1$ earthquake [QRCMT 2012] that occurred in the eastern Po Plain. The mainshock was preceded a few hours before by a $\mathrm{M}_{\mathrm{W}} 4.3$ shock, and it was followed by a dozen $\mathrm{M}_{\mathrm{L}}>4$ aftershocks in May and June, amongst which 11 had $M_{L} \geq 4.5$. On May 29, 2012 , a second $M_{W} 6.0$ mainshock struck roughly the same area [QRCMT 2012], which resulted in further victims, most of whom were caught under the collapse of industrial warehouses. Such earthquakes are an unexpected event in this region, as testified by the lack of local epicenters in the Italian seismic catalog [Rovida et al. 2011: CPTI11 from now] and by the consequent low level of the local seismic classification (seismic zone 3) [DPC 2012].

Apart from the warehouses and hundreds of old, crumbling farmsteads, severe damage was focused on ancient, tall buildings, such as churches, bell towers, castles, towers and palaces. Residential buildings generally suffered only light and/or moderate effects, apart from some exceptional cases. Using the Mercalli-Cancani-Sieberg (MCS) scale [Sieberg 1930], we began a macroseismic survey in the early morning of May 20, 2012, that ultimately included visits to almost 200 localities, 52 of which were carried out before the second mainshock.

\section{Hints on the local historical seismicity}

According to historical sources, the area hit in 2012 has not been affected by events with epicentral intensity $\mathrm{I}_{\mathrm{O}}>6$ MCS, which, conversely, have fallen at the eastern and western boundaries of this region hit in May 2012 (Figure 1). The strongest event occurred in 1570 (November 17; $\mathrm{I}_{\mathrm{O}}$ 7-8 MCS, $\left.M_{W} 5.46\right)$, ca. $35 \mathrm{~km}$ from the 2012 epicenters, and it is also the only earthquake that has hit some of the villages that were affected by the 2012 sequence. Its mesoseismic area is NW-SE elongated [Postpischl 1985], which parallels the local buried front of the Ferrara thrusts [Pieri and Groppi 1981, Cassano et al. 1986], which are, in turn, the eastern prolon- gation of the fronts likely to have been activated in the 2012 sequence. As in 2012, the 1570 sequence recorded more mainshocks, which lasted at least until 1572, and many localities were affected by liquefaction phenomena. These occurred mainly around Ferrara, and up to Ficarolo, on the left bank of the Po River [in Galli 2000, see Figure 1].

Prior to 1570, a coeval chronicle [Giacomo da Marano, 15 th century] suggested that there was another strong earthquake in Ferrara in the year 1346, when on February 22, "many houses fell down, palaces, towers... and in the villages, tenements, barns... and other buildings". However, due to the little information available, this could really have occurred anywhere around Ferrara, and for instance, also in the eastern part of the region that was hit in 2012. The DBMI11 (the Italian macroseismic database) [Locati et al. 2011] reports also two minor earthquakes ( $\mathrm{I}_{\mathrm{O}} 6 \mathrm{MCS}$ ) within the 2012 mesoseismic area: one that occurred on December 6, $1986\left(\mathrm{M}_{\mathrm{W}} 4.35\right)$, and the second on May 8, $1987\left(\mathrm{M}_{\mathrm{W}}\right.$ 4.56).

On October 15, 1996, at the western boundary of the investigated area, an earthquake with MW 5.41 (CPTI11; $\mathrm{I}_{\mathrm{O}} 7 \mathrm{MCS}$ ) [De Canini et al. 1997] affected mainly Bagnolo in Piano and Correggio, where severe damage was observed to a few ancient buildings, as well as light cracks in many brick and masonry buildings, and also in two reinforced-concreteframe structures. At that time, the earthquake was associated with the rupture of the left lateral ramp of the Cavone thrust [De Canini et al. 1997]; i.e., the western prolongation of the Mirandola structure. Further north, a similar earthquake in 1806 caused damage in Correggio (7 MCS), and in other localities hit by the 2012 sequence, such as Reggiolo and Carpi (6-7 MCS).

We can conclude that in the period of earthquake completeness for such a class of magnitude [Stucchi and Albini 2000], the epicentral area of the 2012 events has never generated earthquakes with energy comparable to this current sequence. Moreover, it has probably never been affected by damage from external earthquakes, with the exception of those related to the 1570 Ferrara event, in the easternmost 


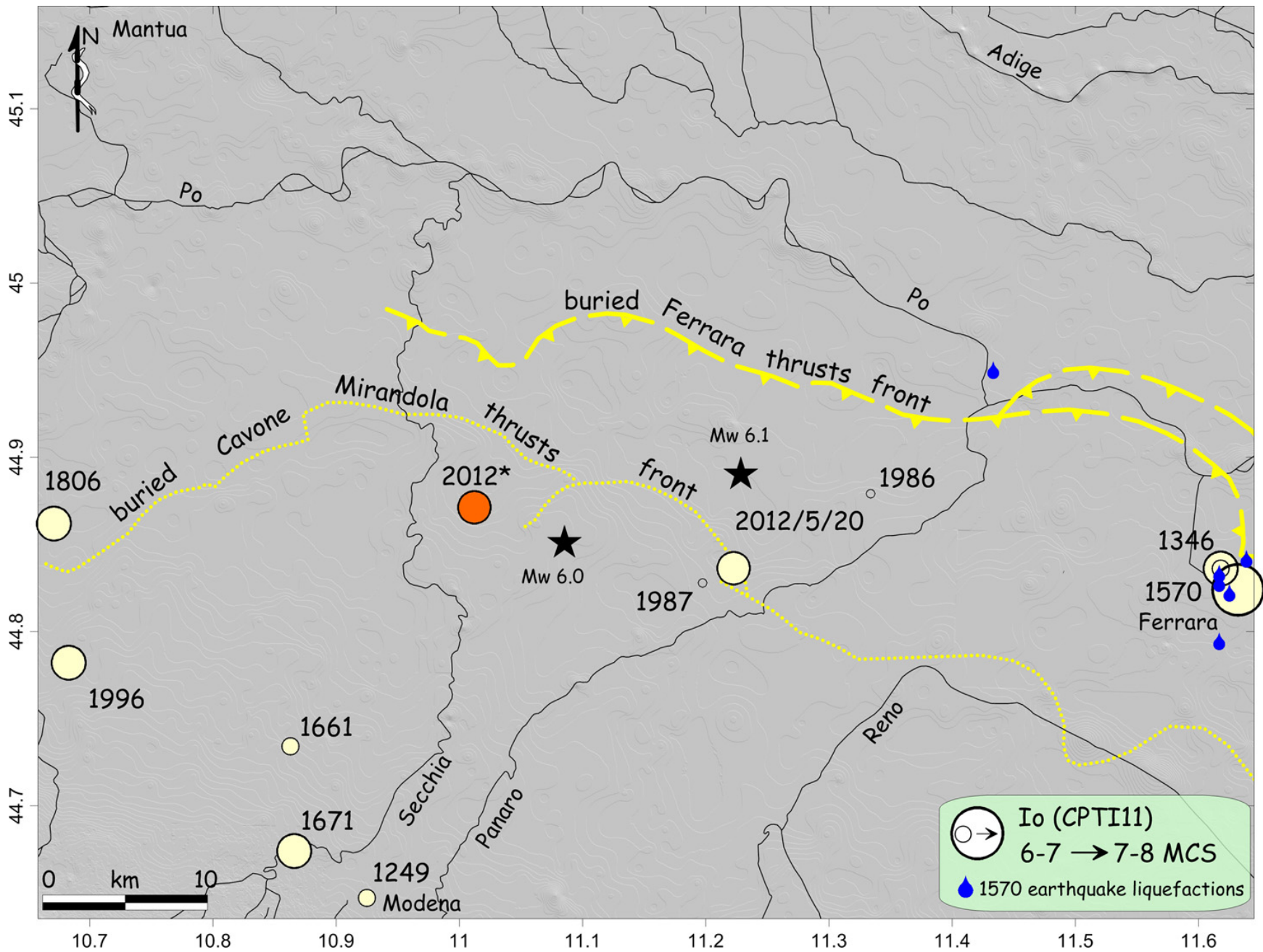

Figure 1. Distribution of the historical epicenters (CPTI11) within the area hit by the 2012 sequence. Stars, instrumental epicenters of May 20 and 29 , 2012; orange ${ }^{\star}$, macroseismic epicenter of the cumulated effects of the May 20 and 29, 2012, events; dotted and dashed yellow lines, buried front of the Cavone-Mirandola and Ferrara folds and thrusts. The 1570 earthquake-induced liquefactions are from Galli [2000]. Note the absence of significant historical epicenters in the 2012 seismic sequence area.

portion, and to the 1806 and 1996 events, in the westernmost portion. Therefore, it is likely that the 2012 mainshocks represent the first, and in some places the last, anti-seismic testing for the historical buildings of this region.

\section{The 2012 MCS macroseismic survey}

Our site intensity $\left(\mathrm{I}_{\mathrm{S}}\right)$ attribution was achieved by applying the MCS macroseismic scale, i.e., the scale adopted for the whole of the Italian macroseismic database (DBMI11), and not the more recent European macroseismic scale (EMS) [Grünthal 1998]. Indeed, as the MCS scale does not fully account for the vulnerability of each single building, it allows a more expeditious application during surveys, which provides the information that is directly correlated to the damage level. We adopted the methodology proposed by Molin [2003, 2009], who differentiated five damage levels (1-5: light, moderate, severe, destruction, collapse), with the calculation of the percentages of damage as $5 \%, 25 \%, 50 \%$, $75 \%$ and $100 \%$, which are representative of each MCS degree, as implicitly contained in the original scale [Sieberg 1930; e.g., in Galli et al. 2012].

\subsection{The May 20 earthquake survey}

We surveyed 52 localities belonging to 30 municipalities in the provinces of Modena, Ferrara and Mantua. This revealed the area of the most severe effects $\left(\mathrm{I}_{S} \geq 6 \mathrm{MCS}\right)$, which was WNW-ESE elongated to the west of the instrumental epicenter, in agreement with the focal mechanism of the mainshock (Figure 2). This area completely matches the hangingwall of the outer Ferrara thrusts front (Figures 1, 2, and the associated focal mechanisms); i.e., the seismogenetic structure responsible for this cluster of the sequence [Galli et al. 2012]. Outside of this area, both to the west and to the east, we observed an intensity increase, in the Moglia, and San Carlo areas, respectively. The maximum intensity $\left(\mathrm{I}_{\max }\right)$ was 7 MCS, which was assigned to Mirandola and San Felice sul Panaro (Figure 2), while $\mathrm{I}_{S}$ 6-7 was evaluated for Finale Emilia, Canaletto, Mortizzuolo and San Carlo, and $\mathrm{I}_{\mathrm{S}} \leq 6 \mathrm{MCS}$ for all of the other localities. The $\mathrm{I}_{\mathrm{O}}$ derived through Boxer4 [Gasperini et al. 2010] was 7 MCS, with a much lower equivalent moment magnitude $\left(\mathrm{M}_{\mathrm{W}}\right.$ 5.1) than the instrumental value $\left(M_{W} 6.11\right)$, while the macroseismic epicenter was ca. $5 \mathrm{~km}$ south of the instrumental epicenter (Figure 2; Table 1). 


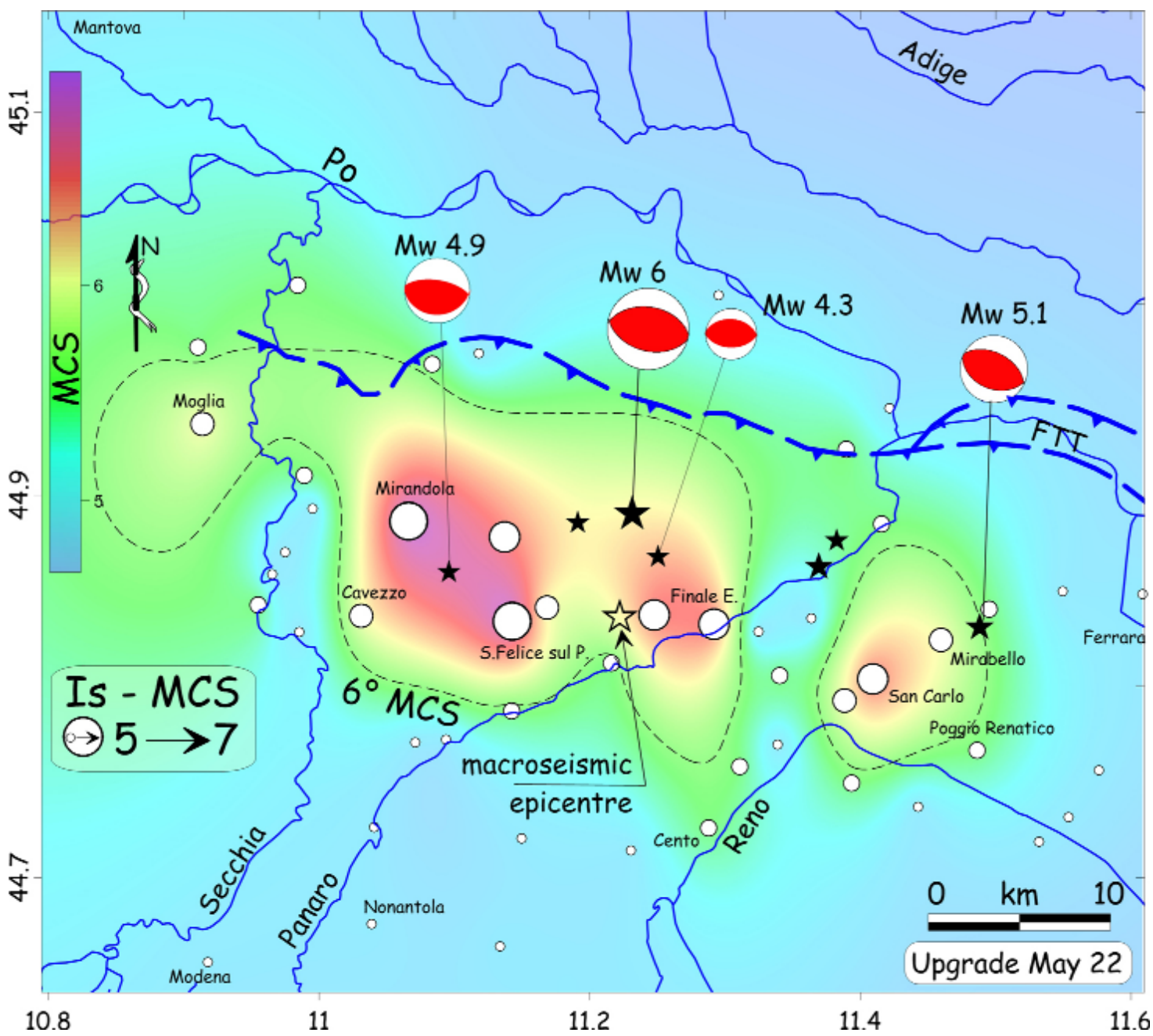

Figure 2. Intensity datapoint distribution of the May 20, 2012, mainshock (white circles, proportional to MCS degrees). The background image indicates the areal shaking in MCS terms. Dashed line, interpolated 6 MCS isoseismal; dashed blue line, buried front of Ferrara thrusts (see Figure 1) to which the focal mechanisms are referred [Time Domain Moment Tensor, TDMT 2012, QRCMT 2012].

\begin{tabular}{|c|c|c|c|c|c|c|c|c|c|}
\hline \multirow[t]{2}{*}{ Date } & \multirow[t]{2}{*}{$\begin{array}{l}\text { Time } \\
(\mathrm{GMT})\end{array}$} & \multicolumn{2}{|c|}{$\begin{array}{l}\text { Instrumental } \\
\text { coordinates }\end{array}$} & \multirow[t]{2}{*}{$\begin{array}{l}\text { Depth } \\
(\mathrm{km})\end{array}$} & \multirow[t]{2}{*}{$\begin{array}{c}\mathrm{M}_{\mathrm{L}} \\
\mathrm{CNT}\end{array}$} & \multirow[t]{2}{*}{$\begin{array}{c}\mathrm{M}_{\mathrm{W}} \\
\mathrm{RCMT}\end{array}$} & \multicolumn{2}{|c|}{$\begin{array}{l}\text { Macroseismic } \\
\text { coordinates }\end{array}$} & \multirow[t]{2}{*}{$\begin{array}{c}\mathrm{I}_{\mathrm{O}} \\
(\mathrm{MCS})\end{array}$} \\
\hline & & $\begin{array}{l}\text { Latitude } \\
\qquad\left({ }^{\circ} \mathbf{N}\right)\end{array}$ & $\begin{array}{c}\text { Longitude } \\
\quad\left({ }^{\circ} \mathrm{E}\right)\end{array}$ & & & & $\begin{array}{l}\text { Latitude } \\
\left({ }^{\circ} \mathrm{N}\right)\end{array}$ & $\begin{array}{c}\text { Longitude } \\
\left({ }^{\circ} \mathrm{E}\right)\end{array}$ & \\
\hline May 20, 2012 & 02:03:52.0 & 44.889 & 11.228 & 6.3 & 5.9 & 6.11 & 44.836 & 11.222 & 7 \\
\hline May 29, 2012 & 07:00:03.0 & 44.851 & 11.086 & 10.2 & 5.8 & 5.96 & 44.877 & 11.004 & 7 \\
\hline
\end{tabular}

Table 1. Instrumental and macroseismic parameters of the two mainshocks of the Emilia 2012 sequence (INGV source, and the present study). The May 29, 2012, string accounted for the cumulated effects of the sequence. GMT, Greenwich Mean Time; CNT, National Earthquake Center (INGV); RCMT, Regional Centroid Moment Tensor; MCS, Mercalli-Cancani-Sieberg.

Most of the heavy damage, which included total and partial collapses, affected tall historical buildings, such as churches, bell towers, towers, castles (Figure 3), palaces, and ancient farmhouses, as well as many industrial warehouses on the outskirts of Mirandola and Sant'Agostino (Figure 4).

The residential housing estates generally suffered lowgrade damage (levels 1-2), both for brick and masonry (reinforced or not) and for reinforced concrete. There was sparse severe damage (level 3) and very rare partial collapse (usually of roof ledges, roofs and loading docks of crumbling houses) or destruction (level 4), as well as diffuse falls of chimneys, tiles and plaster, which occurred almost everywhere within the old downtown areas. This explains why this night earthquake resulted in a limited number of victims (9), almost all of whom were night-shift workers in the industrial warehouses. Severe damage to reinforced-concrete buildings was observed in one case inside Mirandola and in three others on its northern outskirts (light crushing of pillars and cracks on the brick-curtain walls), as in some apartment houses in Cavezzo. 

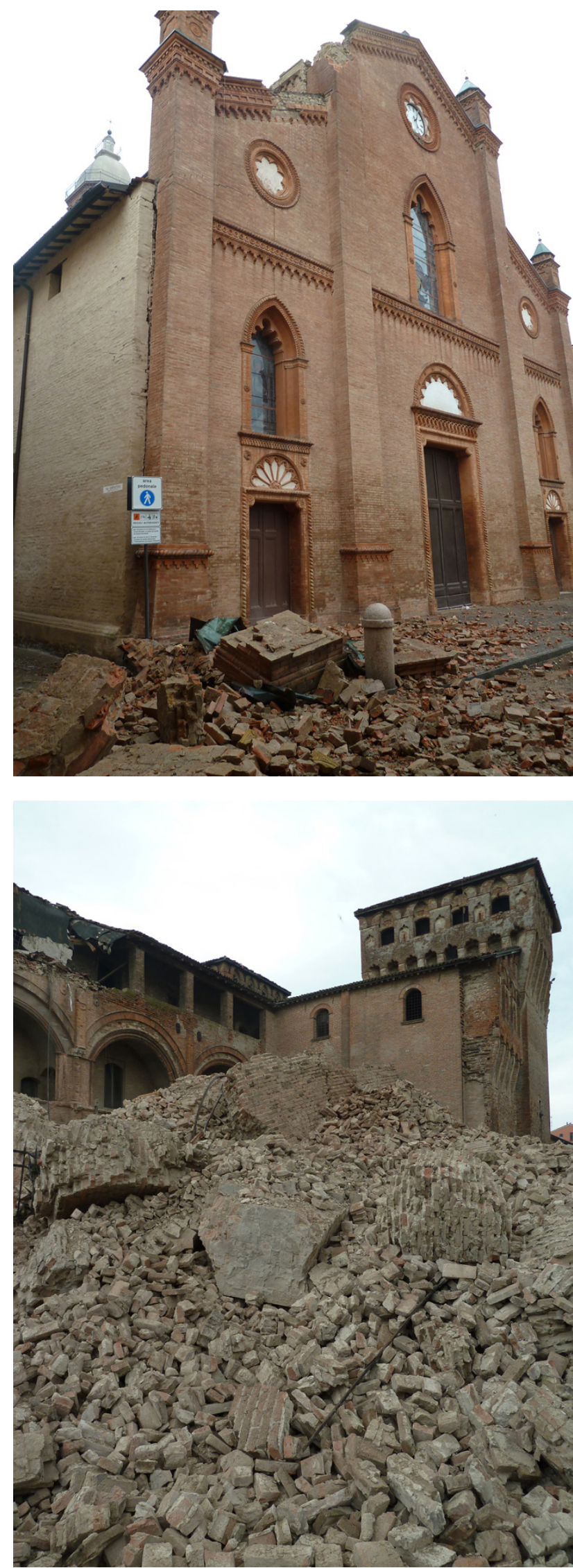

Figure 3. The morning of May 20, 2012. Top: View of the Mirandola Cathedral (15th century). At that time, only a few architectural elements at the top of the façade had fallen down, besides the incipient façade detachment. The church was damaged again, and more seriously, by the May 29, 2012, mainshock. Bottom: Partial collapse of the Estense Castle (15th century) in Finale Emilia.
In some cases, the damage was increased due to the huge liquefaction phenomenon that affected the deposits below the buildings, with the consequent loss of weightbearing capacity, and differential settling and/or tilting of foundations. Liquefaction occurred extensively in the villages located over the paleo-beds of the main rivers, such as in Sant'Agostino, San Carlo and Mirabello, all of which were founded along the abandoned Reno fluvial ridge. Here, as well as the damage to buildings, the surficial breaks induced by the liquefaction settling processes also affected roads and pipelines. As can be seen from Figure 2, it emerges that the intensity bulge at the eastern side of the mesoseismic area is merely due to these liquefaction effects, and not just to the seismic shaking of buildings.

In the more distant towns of the Po Plain, there was no severe damage, and not even to isolated buildings. In Mantua and Modena the damage was limited to levels 1-2, to only a very few houses, while Ferrara experienced levels 1-2 to several old houses downtown, mostly related to pre-existing cracks. We recorded the fall or rotation of a dozen chimneys, tiles, and sparse architectural elements hanging on the church façades, as well as the partial collapse of a small tower over the Estense Castle.

We did, however, have trouble in evaluation of the $\mathrm{I}_{\mathrm{S}}$ in many localities (Appendix 1, Table A1), because of the extreme differences in the damage levels between recent residential housing (usually 1-2 storeys, reinforced brick and masonry villas) and the historical monument buildings. As in the L'Aquila 2009 earthquake $\left(\mathrm{M}_{\mathrm{W}}\right.$ 6.3) [Galli et al. 2009], we chose to take more into account the effects recorded by the buildings inside the old centers, and to exclude entirely the damage to industrial warehouses.

\subsection{The May 29, 2012, earthquake survey}

We re-started the macroseismic survey on the morning of May 29, 2012, visiting again the villages hit by the May 20, 2012, event, for up to 190 localities belonging to 87 municipalities (Figure 5). We observed an increase of 1-2 MCS degrees in some villages in the western part of the area, with severe damage in Reggiolo ( $\mathrm{I}_{\mathrm{S}}$ 6-7 MCS), Novi di Modena ( $\mathrm{I}_{\mathrm{S}} 7 \mathrm{MCS}$ ), Concordia sulla Secchia $\left(\mathrm{I}_{\mathrm{S}} 7 \mathrm{MCS}\right.$; with some partial collapse and severe damage to the front porches of buildings), Moglia ( $\mathrm{I}_{\mathrm{S}} 7 \mathrm{MCS}$ ), and Rovereto $\left(\mathrm{I}_{\mathrm{S}}=\mathrm{I}_{\max } 7-8\right.$ MCS; maximum intensity assigned in this earthquake). This last was where various partial collapsing and heavy damage occurred, both in the brick and masonry houses of the old center and in some of the recent reinforced-masonry and reinforced-concrete buildings. In the other localities generally west of Mirandola, the intensity grew by $<1$ MCS degree. In Mirandola, the May 29, 2012, mainshock and the successive strong aftershock of midday $\left(\mathrm{M}_{\mathrm{W}}\right.$ 5.3) caused the collapse of the 14th century Saint Francis church, which was only slightly damaged by the May 20, 2012, earthquake. More- 
over, it caused further collapse of the Cathedral, and various heavy damage to and partial collapse of the old houses downtown, as well as to some reinforced-concrete buildings already damaged on May 20, 2012. In Cavezzo, the increased damage level also yielded a higher intensity (at least $\mathrm{I}_{\mathrm{S}} 7 \mathrm{MCS}$ ), which was mainly justified by the collapse of the pilotis of three reinforced-concrete buildings (Figure 6) and by the diffusion of level 3 damage to several brick and masonry houses in the old center.

Southwards, outside the $6 \mathrm{MCS}$ isoseismal shown in Figure 5, both Crevalcore and Cento suffered more effects within their old centers, which now showed diffuse level 2 damage to about a quarter of the buildings, with some heavy damage (level 3) and sparse partial collapse of roof-bearing walls.

In turn, the damage area did not extend substantially northwards, although we assigned $\mathrm{I}_{\mathrm{S}}$ 5-6 MCS to several localities near the Po River, and exceptionally also to the north of it (Castelmassa). Heavy damage to isolated monument structures (usually churches or bell towers) and absolutely no damage to residential buildings was observed in many villages, to which we necessarily assigned $\mathrm{I}_{\mathrm{S}} 5$ MCS. However, the intensity datapoints listed in Appendix 1 (Table A1) note these effects in column DJ, where the labels A, B and C indicate heavy damage to and/or collapse of buildings, towers or bell towers, and churches.

Overall, the 6 MCS area extended westwards, to reach a length of $35 \mathrm{~km}$; i.e., $10 \mathrm{~km}$ more with respect to the May 20, 2012, event. Also, two extreme intensity bulges were seen to the west and the east: the first was now focused on Reggiolo (it was on Moglia before), while the second was again that occupied by San Carlo and Mirabello. Considering also these areas, the $6 \mathrm{MCS}$ is ca. $55 \mathrm{~km}$ elongated WNW-ESE, with a N-S width of $15 \mathrm{~km}$ to $20 \mathrm{~km}$. As seen from Figure 5, and assuming a roughly similar vulnerability in all of the surveyed localities, it is probable that the intensity bulges mentioned represent many cases of geological amplification. In one of these, we recognized the strong contribution of the liquefaction phenomenon that occurred extensively all along the paleo-bed of the Reno River, while in the other cases, only future geological analyses will be able to reveal the causes of the seismic shaking increase, hopefully. It is worth noting that also during this shock, several liquefaction phenomena occurred, some in the same places as for the May 20, 2012, event, others in different localities. However, the power of the phenomenon was certainly lower than in the earlier case, and no further damage was reported.

Also for this May 29, 2012, mainshock, our intensity estimates refer mainly to the old center of the surveyed localities, as almost everywhere the earthquake affected these more than the modern outskirts (which were generally affected by sparse 1-2 level damage), apart from some impressive exceptions in Rovereto (collapse of the pilotis of new reinforced brick and masonry 3-storey villas) or Fossoli (level

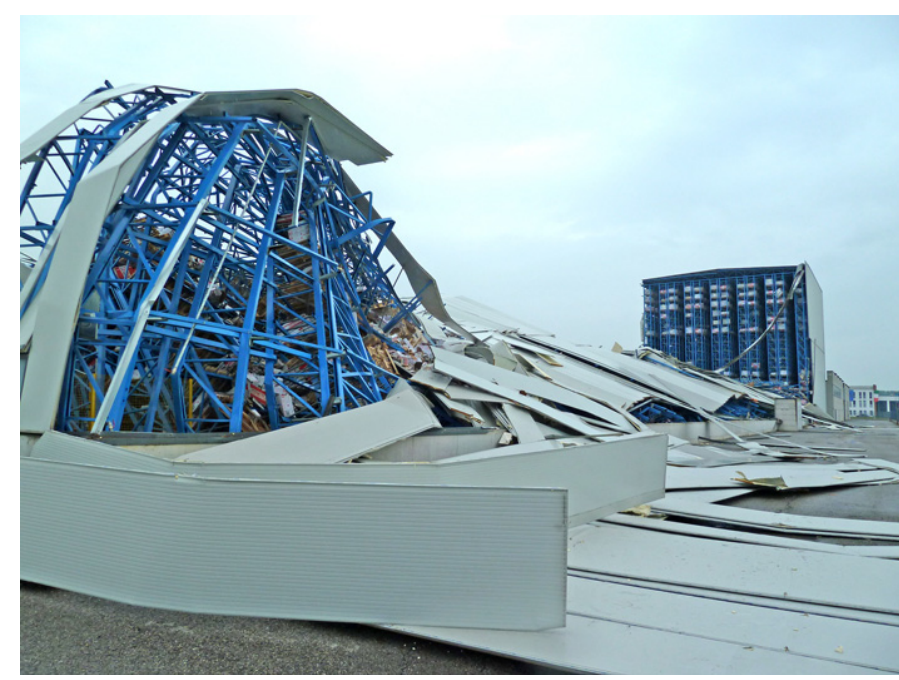

Figure 4. Collapse of the Sant'Agostino ceramics warehouse near Sant' Agostino village.

3 damage to the first and second storeys of some reinforcedconcrete buildings). In some villages (e.g., Cento, Concordia, Crevalcore, Moglia, Reggiolo, San Giacomo delle Segnate), the damage was diffuse in the porch houses; i.e., the typical buildings of almost all of the main streets of the Po Plain settlements. Here, we often observed level 2 and 3 cracks that affected the columns and/or the pillars of the arches, with consequent damage to the overlying wall of the first/second storey.

The $\mathrm{I}_{\mathrm{O}}$ of the cumulated sequence (mainly from May 20 and 29, 2012) calculated through Boxer4 was again 7 MCS, with an equivalent magnitude always lower $\left(\mathrm{M}_{\mathrm{W}}\right.$ 5.23) with respect to the instrumental one $\left(M_{W} 6.11\right.$ plus $M_{W}$ 5.96). The final epicentral coordinates (Table 1) identified a point located more than $15 \mathrm{~km}$ west of both the instrumental and macroseismic epicenters of May 20,2012, and $5 \mathrm{~km}$ west of the instrumental epicenter of May 29, 2012 (Figure 5). This westward drift of the barycenter of the macroseismic effects with respect to the instrumental ones might roughly indicate the rupture direction along the structures responsible at depth for this sequence; i.e. from east to west.

\section{Discussion and conclusions}

We applied the MCS scale [Sieberg 1930] for the macroseismic survey of 190 localities in the Provinces of Mantua, Rovigo, Ferrara, Modena and Reggio Emilia, using the methodology proposed by Molin [2009]. On the one hand, the resulting intensity datapoint distribution (IDD) meets the primary purposes of the civil protection intervention (rescue and emergency planning based on real damage, leaving vulnerability out of the consideration), and on the other hand, it can be directly compared to the historical earthquakes contained in the Italian seismic database. We compiled a preliminary IDD also for the May 20, 2012, mainshock, composed of 52 datapoints (Appendix 1, Table A1). The highest IDD (HIDD) for both of the mainshocks 


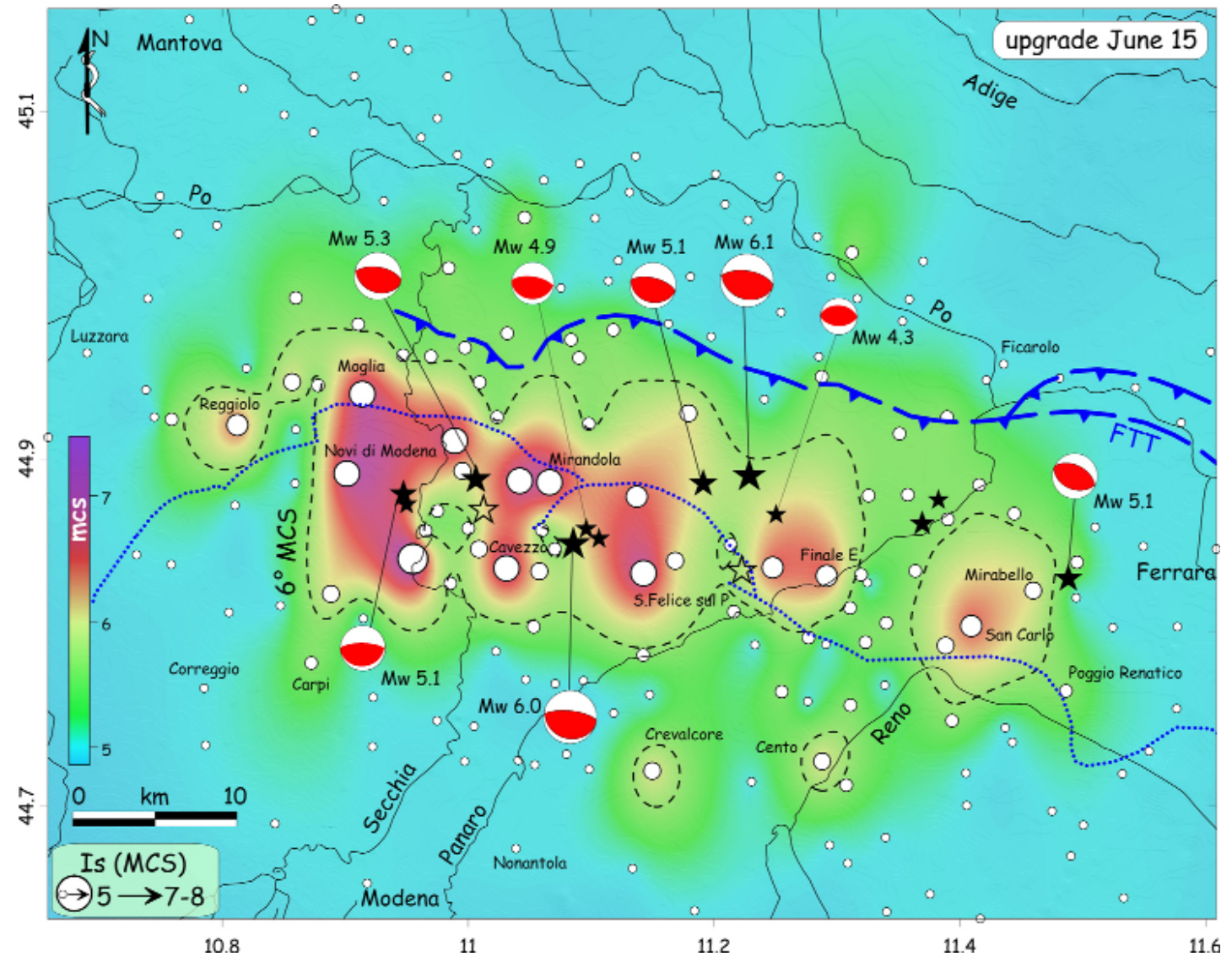

Figure 5. Intensity datapoints distribution of the whole of the 2012 sequence. The color image in the background suggests the areal shaking in terms of the MCS intensity. Black dashed line, the 6 MCS degree isoseismal as interpolated from the intensity data; dashed and dotted blue lines, the Ferrara and Cavone-Mirandola thrust fronts, respectively, i.e., the structures responsible for the whole sequence; black stars, the main events, with their associated focal mechanisms [TDMT 2012, QRCMT 2012]. The two empty stars are the macroseismic epicenters of the May 20, 2012, (east) and of the cumulated May 20 plus 29, 2012, mainshocks (west).

fits with the hangingwall of the two main buried thrust fronts of the region, with the May 20, 2012, HIDD lying entirely south of the outer Ferrara thrust fronts, and the May 29, 2012, HIDD lying south of the Mirandola-Cavone thrust (Figures 1, 5). Therefore, considering the entire extension of the arched, outer Ferrara thrust fronts and the intermediate

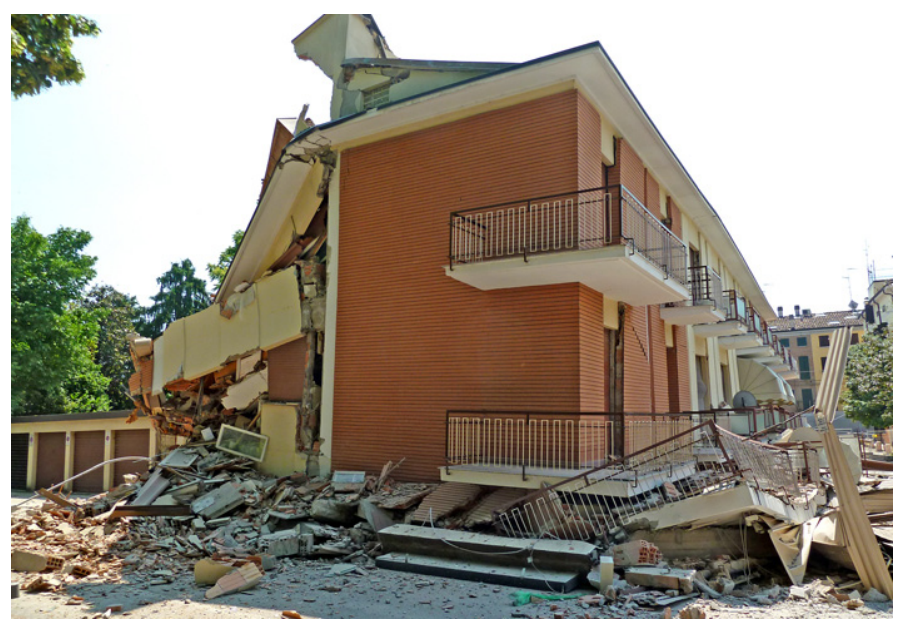

Figure 6. Cavezzo ( $\left.\mathrm{I}_{\mathrm{S}} 7 \mathrm{MCS}\right)$. Total collapse of the pilotis of a reinforcedconcrete building in the old center (photo taken on the morning of May 29, 2012). This building experienced level 2 damage because of the May 20 mainshock, and was not inhabited when it collapsed on May 29.
Cavone-Mirandola buried folds and thrusts (Figure 5), and considering the historical seismicity of the same region (Figure 1), the 2012 sequence partially filled the seismic gap that existed between the earthquakes in the Ferrara area to the east (i.e., 1570) and those around Correggio to the west (i.e., $1806,1996)$. This confirms the assumed residual activity of these buried structures [e.g., in Galli 2005, Scrocca et al. 2007].

The equivalent magnitude estimated through Boxer4 [Gasperini et al. 2010] was much lower than the instrumental one $\left(M_{W} 5.23 v s M_{W} 6.1\right)$. If we had really only considered the damage that affected the ancient houses (excluding all those not only on the recent outskirts, but also the new buildings inside the old centers), our intensities would have been higher by 0.5 to 1.0 degree. Of particular note, this would not be everywhere, as for instance in Cavezzo or Fossoli, it would have been lower, where the damage affects mainly modern, reinforced-concrete buildings. However, this increase is not enough to equal the instrumental magnitude. There is a similar anomaly also when considering the acceleration peaks (e.g., Mirandola, 0.29 g; San Felice sul Panaro, Cento 0.23 g; Moglia, 0.25 g; http: / / www.protezionecivile. gov.it/jcms/it/attivita_di_monitoraggio_dpc.wp), which would account for much more damage with respect to that which actually occurred (e.g., 9 MCS in Mirandola, by con- 
sidering the correlations in Faccioli and Cauzzi [2006]). We must conclude that the quality of the ancient brick and masonry houses in Emilia, and the role played by the deep alluvial deposits in filtering the earthquake frequency content, might have concurred in this mitigation of the shaking effects on most of the building typologies (although, unfortunately not for monument buildings), despite the relative high magnitudes and acceleration peaks.

\section{References}

Cassano, E., L. Anelli, R. Fichera and V. Cappelli (1986). Pianura Padana. Interpretazione integrata di dati geofisici e geologici, $73^{\circ}$ Congresso della Società Geologica Italiana (Roma, 29 sett.-4 ott.), 27 pp.

De Canini, L., G. Di Pasquale, G. Orsini, R. Colozza, P. Galli, A. Marcucci, G. Milana, D. Molin and A. Pugliese (1997). Ricognizione degli effetti del sisma del 15 ottobre 1996 in provincia di Reggio Emilia, Dipartimento dei Servizi Tecnici Nazionali, Servizio Sismico Nazionale, Rapporto Tecnico SSN/RT/97/4, $191 \mathrm{pp}$.

DPC (2012). Classificazione sismica al 2012. Recepimento da parte delle Regioni e delle Provincie autonome dell'Ordinanza PCM 20 Marzo 2003, n. 3274, Dipartimento della Protezione Civile, http:/ / www.protezionecivile.gov.it/ resources/cms/documents/class2012_02prov.pdf (last access July 2012).

Faccioli, E., and C. Cauzzi (2006). Macroseismic intensities for seismic scenarios estimated from instrumentally based correlations, In: Proceedings of the First European Conference on Earthquake Engineering and Seismology (Geneva, 3-8 September 2006), CD-ROM.

Galli, P. (2000). New empirical relationships between magnitude and distance for liquefaction, Tectonophysics, 324, 169-187.

Galli, P. (2005). I terremoti del Gennaio 1117. Ipotesi di un epicentro nel cremonese, Il Quaternario, 18, 87-100.

Galli, P., R. Camassi, R. Azzaro, F. Bernardini, S. Castenetto, D. Molin, E. Peronace, A. Rossi, M. Vecchi and A. Tertulliani (2009). Il terremoto aquilano del 6 aprile 2009: rilievo macrosismico, effetti di superficie ed implicazioni sismotettoniche, Il Quaternario, 22, 235-246.

Galli, P., S. Castenetto and E. Peronace (2012). May 2012 Emilia earthquakes $\left(\mathrm{M}_{\mathrm{W}} 6\right.$, northern Italy): macroseismic effects distribution and seismotectonic implications, Alpine and Mediterranean Quaternary, 25 (2), 105-123.

Gasperini, P., G. Vannucci, D. Tripone and E. Boschi (2010). The location and sizing of historical earthquakes using the attenuation of macroseismic intensity with distance, B. Seismol. Soc. Am., 100, 2035-2066; doi: 10.1785/01200 90330.

Giacomo da Marano (15th century). Cronaca inedita di Ferrara estense dal 1298 al 1412, In: Bollettino statistico del Comune di Ferrara, 56-58, 1929-1931.
Grünthal, G., ed. (1998). European Macroseismic Scale 1998 (EMS-98). European Seismological Commission, subcommission on Engineering Seismology, working Group Macroseismic Scales. Conseil de l'Europe, Cahiers du Centre Européen de Géodynamique et de Séismologie, 15, Luxembourg.

Locati, M., R. Camassi and M. Stucchi (2011). DBMI11, the 2011 version of the Italian Macroseismic Database, Milano/Bologna; http: / / emidius.mi.ingv.it/DBMI11 (last access July 2012).

Molin, D. (2003). Considerazioni sull'eventuale adozione in Italia della scala macrosismica europea (EMS- 1998), In: GNGTS - Atti del $22^{\circ}$ convegno nazionale/06.21, ISBN/ISSN:88-900385-9-4, 11 pp.

Molin, D. (2009). Rilievo macrosismico in emergenza, Rapporto interno Dipartimento della Protezione Civile; Ufficio III Valutazione, prevenzione e mitigazione del rischio sismico, $13 \mathrm{pp}$.

Pieri, M., and G. Groppi (1981). Subsurface geological structure of the Po Plain (Italy), C.N.R., Progetto Finalizzato Geodinamica, 414, 1-13.

Postpischl, D. (1985). Atlas of isoseismal maps of Italian earthquakes, Bologna, $164 \mathrm{pp}$.

QRCMT (2012). Quick Regional Centroid Moment Tensor, INGV-Bologna; http:/ / autorcmt.bo.ingv.it/quicks.html (last access July 2012).

Rovida, A., R. Camassi, P. Gasperini and M. Stucchi (2011). CPTI11, versione 2011 del Catalogo Parametrico dei Terremoti Italiani, Milano/Bologna; http: / / emidius.mi.ingv. it/ CPTI (last access July 2012).

Scrocca, D., E. Carminati, C. Doglioni and D. Marcantoni (2007). Slab retreat and active shortening along the central-northern Apennines, In: O. Lacombe, J. Lavè, F. Roure and L. Verges L. (eds.), Thrust belts and foreland basins: From fold kinematics to hydrocarbon systems, Frontiers in Earth Sciences, 471-487.

Sieberg, A. (1930). Geologie der Erdbeben, Handbuch der Geophysik, 4, 552-554.

Stucchi, M., and P. Albini (2000). Quanti terremoti abbiamo perso nell'ultimo millennio?, In: F. Galadini, C. Meletti and A. Rebez (eds.), Le ricerche del GNDT nel campo della pericolosità sismica (1996-1999), CNR-GNDT, 333-343.

TDMT (2012). Time Domain Moment Tensor, INGV-Centro Nazionale Terremoti; http:/ / cnt.rm.ingv.it/tdmt.html (last access July 2012).

\footnotetext{
${ }^{\star}$ Corresponding author: Paolo Galli,

Dipartimento della Protezione Civile, Roma, Italy;

email: paolo.galli@protezionecivile.it.

C 2012 by the Istituto Nazionale di Geofisica e Vulcanologia. All rights reserved.
} 
Appendix 1

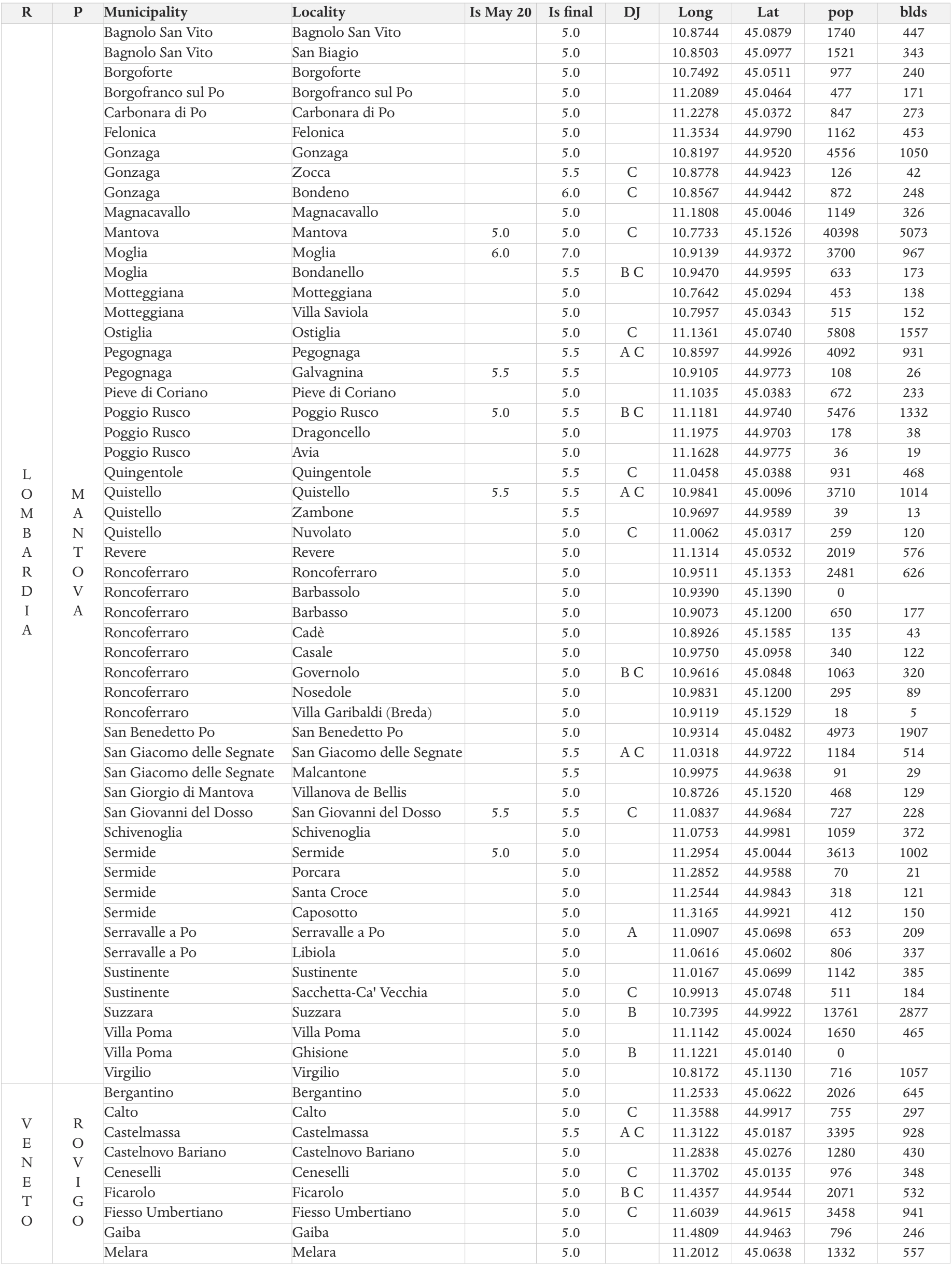




\begin{tabular}{|c|c|c|c|c|c|c|c|c|c|c|}
\hline $\mathbf{R}$ & $\mathbf{P}$ & Municipality & Locality & Is May 20 & Is final & DJ & Long & Lat & pop & blds \\
\hline & & Occhiobello & Occhiobello & & 5.0 & & 11.5800 & 44.9208 & 2004 & 368 \\
\hline & & Stienta & Stienta & & 5.0 & & 11.5428 & 44.9410 & 1647 & 416 \\
\hline & & Campagnola Emilia & Campagnola Emilia & & 5.0 & & 10.7584 & 44.8392 & 3928 & 826 \\
\hline & $\begin{array}{l}\mathrm{R} \\
\mathrm{F}\end{array}$ & Correggio & Correggio & & 5.0 & & 10.7850 & 44.7679 & 13480 & 2333 \\
\hline & E & Fabbrico & Fabbrico & & 5.0 & $\mathrm{C}$ & 10.8102 & 44.8732 & 4879 & 802 \\
\hline & G & Guastalla & Guastalla & & 5.0 & & 10.6584 & 44.9122 & 11087 & 2339 \\
\hline & G & Luzzara & Luzzara & & 5.0 & & 10.6899 & 44.9608 & 4090 & 942 \\
\hline & $\begin{array}{l}1 \\
0\end{array}$ & Luzzara & Villarotta & & 5.0 & & 10.7446 & 44.9240 & 1291 & 328 \\
\hline & 0 & Luzzara & Casoni & & 5.0 & $\mathrm{C}$ & 10.7380 & 44.9396 & 418 & 150 \\
\hline & $\mathrm{F}$ & Novellara & Novellara & & 5.0 & & 10.7303 & 44.8447 & 9198 & 1922 \\
\hline & $\mathrm{E}$ & Reggiolo & Reggiolo & & 6.5 & & 10.8121 & 44.9194 & 6243 & 1284 \\
\hline & Int & Reggiolo & Villanova & & 5.0 & & 10.8598 & 44.9167 & 387 & 108 \\
\hline & 1 & Reggiolo & Brugneto & & 5.5 & $\mathrm{C}$ & 10.7587 & 44.9227 & 781 & 225 \\
\hline & $\begin{array}{l}\mathrm{L} \\
\mathrm{I}\end{array}$ & Rio Saliceto & Rio Saliceto & & 5.0 & & 10.8054 & 44.8116 & 4442 & 776 \\
\hline & A & Rolo & Rolo & & 5.0 & $\mathrm{C}$ & 10.8592 & 44.8857 & 3188 & 779 \\
\hline & & San Martino in Rio & San Martino in Rio & & 5.0 & & 10.7863 & 44.7353 & 4963 & 863 \\
\hline & & Bastiglia & Bastiglia & & 5.0 & & 10.9972 & 44.7259 & 3005 & 427 \\
\hline & & Bomporto & Bomporto & 5.0 & 5.0 & & 11.0407 & 44.7265 & 2265 & 422 \\
\hline & & Bomporto & Sorbara & & 5.0 & & 11.0047 & 44.7460 & 2683 & 451 \\
\hline & & Bomporto & Gorghetto & 5.0 & 5.0 & & 11.0709 & 44.7706 & 350 & 89 \\
\hline & & Bomporto & Solara & 5.0 & 5.0 & A B & 11.0939 & 44.7722 & 1096 & 234 \\
\hline & & Campogalliano & Campogalliano & & 5.0 & & 10.8429 & 44.6900 & 5890 & 793 \\
\hline & & Camposanto & Camposanto & 5.5 & 5.5 & A B C & 11.1422 & 44.7871 & 2264 & 490 \\
\hline & & Camposanto & Ca' Bianca & 5.5 & 5.5 & & 11.2160 & 44.8120 & 21 & 11 \\
\hline & & Carpi & Carpi Centro & & 5.5 & $\mathrm{C}$ & 10.8724 & 44.7825 & 49658 & 6631 \\
\hline & & Carpi & San Marino & & 5.0 & & 10.9148 & 44.8081 & 1354 & 291 \\
\hline $\mathrm{E}$ & & Carpi & Migliarina & & 5.0 & & 10.8471 & 44.8154 & 1485 & 337 \\
\hline M & & Carpi & Fossoli & & 6.0 & & 10.8884 & 44.8222 & 2756 & 479 \\
\hline I & & Cavezzo & Cavezzo & 6.0 & 7.0 & & 11.0310 & 44.8369 & 4964 & 1027 \\
\hline $\mathrm{L}$ & & Cavezzo & Motta & 5.0 & 5.5 & B & 10.9855 & 44.8284 & 19 & 13 \\
\hline I & & Cavezzo & La Bottega & & 6.0 & & 11.0089 & 44.8481 & 159 & 46 \\
\hline A & & Cavezzo & Disvetro & & 5.5 & $\mathrm{C}$ & 11.0003 & 44.8600 & 128 & 40 \\
\hline & & Concordia sulla Secchia & Concordia sulla Secchia & 5.5 & 7.0 & & 10.9890 & 44.9103 & 4414 & 991 \\
\hline $\mathrm{R}$ & & Concordia sulla Secchia & Fossa & & 5.5 & & 11.0235 & 44.9240 & 1298 & 388 \\
\hline $\mathrm{O}$ & & Concordia sulla Secchia & Vallalta & & 5.5 & $\mathrm{C}$ & 11.0094 & 44.9440 & 503 & 137 \\
\hline M & & Finale Emilia & Finale Emilia & 6.5 & 6.5 & & 11.2917 & 44.8326 & 8567 & 1711 \\
\hline A & & Finale Emilia & Reno Finalese & & 5.5 & $\mathrm{C}$ & 11.3197 & 44.8333 & 148 & 57 \\
\hline G & M & Finale Emilia & Canaletto & 6.5 & 6.5 & & 11.2477 & 44.8373 & 48 & $?$ \\
\hline $\mathrm{N}$ & $\mathrm{O}$ & Finale Emilia & Massa Finalese & & 5.5 & $\mathrm{C}$ & 11.2135 & 44.8503 & 4061 & 934 \\
\hline A & $\mathrm{D}$ & Medolla & Medolla & & 5.5 & B C & 11.0704 & 44.8480 & 4189 & 999 \\
\hline & $\mathrm{E}$ & Medolla & Villafranca & & 6.0 & & 11.0578 & 44.8352 & 172 & 66 \\
\hline & $\mathrm{N}$ & Medolla & San Giacomo Roncole & & 5.5 & B C & 11.0602 & 44.8589 & 72 & 29 \\
\hline & A & Mirandola & Mirandola & 7.0 & 7.0 & & 11.0660 & 44.8864 & 15414 & 2814 \\
\hline & & Mirandola & Mortizzuolo & 6.5 & 6.5 & & 11.1370 & 44.8781 & 729 & 246 \\
\hline & & Mirandola & San Martino Carano & & 7.0 & & 11.0420 & 44.8873 & 168 & 56 \\
\hline & & Mirandola & Quarantoli & & 5.5 & $\mathrm{C}$ & 11.0982 & 44.9202 & 981 & 302 \\
\hline & & Mirandola & Gavello & & 6.0 & & 11.1793 & 44.9261 & 343 & 110 \\
\hline & & Mirandola & San Martino Spino & & 5.0 & & 11.2409 & 44.9341 & 763 & 214 \\
\hline & & Mirandola & Tramuschio & & 5.5 & $\mathrm{C}$ & 11.0902 & 44.9580 & 313 & 105 \\
\hline & & Modena & Modena & 5.0 & 5.0 & & 10.9177 & 44.6559 & 156717 & 13735 \\
\hline & & Nonantola & Nonantola & 5.0 & 5.0 & & 11.0389 & 44.6758 & 8918 & 1053 \\
\hline & & Novi di Modena & Novi di Modena & & 7.0 & & 10.9014 & 44.8915 & 5330 & 1273 \\
\hline & & Novi di Modena & Rovereto & 5.5 & 7.5 & & 10.9551 & 44.8425 & 3207 & 860 \\
\hline & & Ravarino & Ravarino & & 5.0 & B C & 11.0985 & 44.7213 & 3391 & 602 \\
\hline & & Ravarino & Rami & & 5.0 & & 11.0801 & 44.7300 & 0 & \\
\hline & & Ravarino & Casoni & & 5.0 & & 11.0541 & 44.7240 & 335 & 64 \\
\hline & & Ravarino & Stuffione & & 5.0 & & 11.1185 & 44.7536 & 301 & 90 \\
\hline & & San Felice sul Panaro & San Felice sul Panaro & 7.0 & 7.0 & & 11.1425 & 44.8341 & 6421 & 1357 \\
\hline & & San Felice sul Panaro & Rivara & 6.0 & 6.0 & & 11.1684 & 44.8413 & 755 & 189 \\
\hline & & San Possidonio & San Possidonio & 5.0 & 6.0 & & 10.9953 & 44.8929 & 2948 & 760 \\
\hline & & San Possidonio & Forcello & 5.0 & 5.5 & & 10.9751 & 44.8700 & 0 & \\
\hline & & San Possidonio & Pioppa & 5.0 & 5.5 & & 10.9654 & 44.8586 & 81 & 35 \\
\hline & & San Prospero & San Prospero & & 5.0 & B & 11.0226 & 44.7893 & 1794 & 375 \\
\hline & & San Prospero & San Pietro & & 5.0 & A B & 11.0467 & 44.7730 & 559 & 158 \\
\hline
\end{tabular}




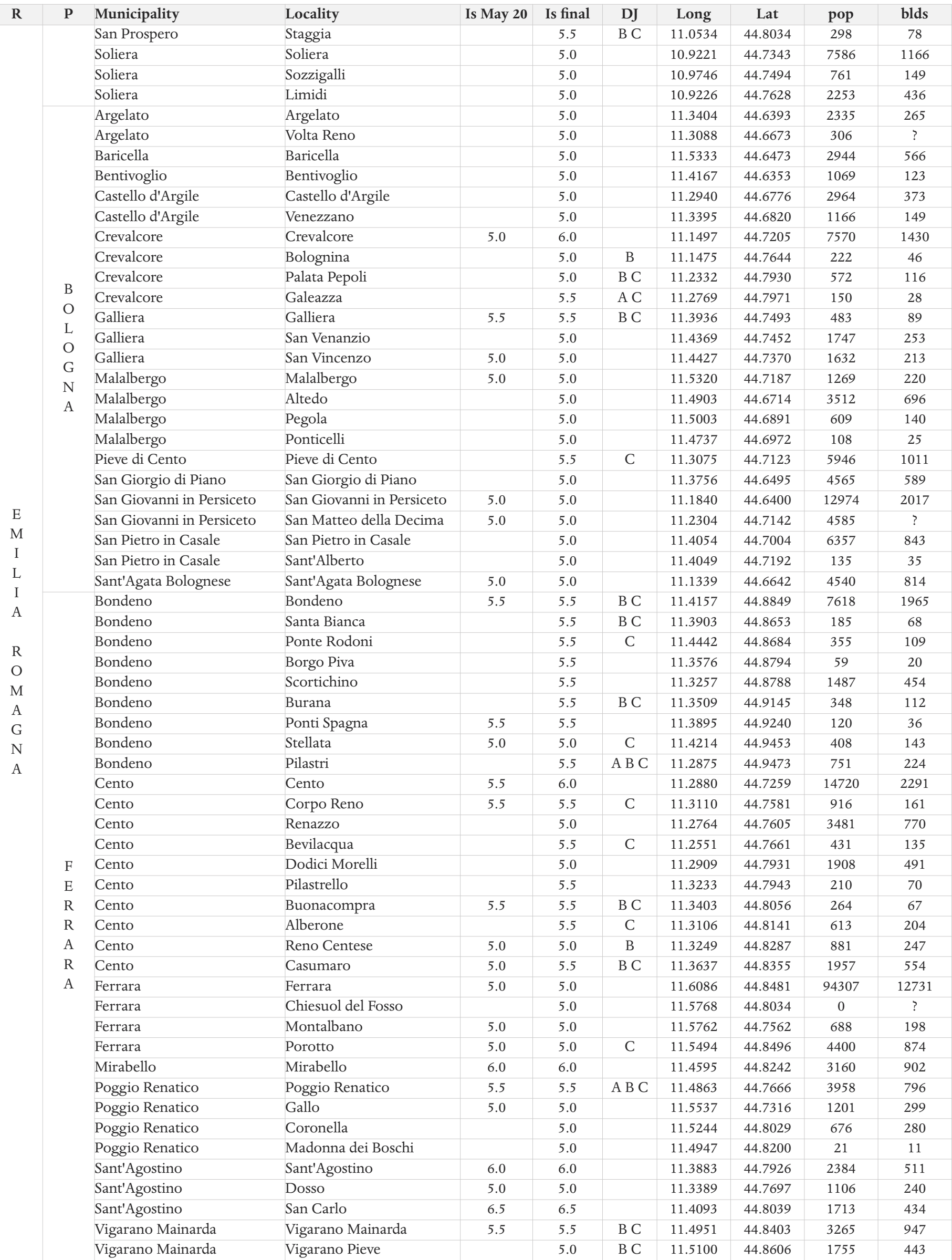

Table A1. MCS intensities ( $\mathrm{I}_{\mathrm{S}}$ ) evaluated for the May 20, 2012, and the May 29, 2012, (accumulated) Emilia earthquakes. R and P, region and province, respectively. DJ, severe damage to isolated buildings $\left(\mathrm{I}_{\mathrm{S}}<6 \mathrm{MCS}\right)$. Pop, blds, number of inhabitants and buildings, respectively. 